\title{
Thinning effects on stand formation and modifications of a young pine/birch forest: a boreal zone case study
}

\author{
Elena Nikolaevna Nakvasina ${ }^{1}$, Alexandra Viktorovna Voevodkina ${ }^{1}$, \\ Alexey Gennadievich Volkov ${ }^{1} \bowtie$, Andrey Yurievich Zakharov², \\ Sergey Viktorovich Koptev ${ }^{1,3}$, Nicolai Stepanovich Minin ${ }^{1,3}$ \\ ${ }^{1}$ Northern (Arctic) Federal University named after M.V. Lomonosov, Northern Dvina Embankment 17, \\ Archangelsk, 163002, Russian Federation, phone:+7 902 5073512, e-mail: a.g.volkov@narfu.ru \\ ${ }^{2}$ Ministry for Natural Resources and Lumber Industry of the Arkhangelsk Region, Viycheiskogo str. 18, \\ Archangelsk, 163000, Russian Federation \\ ${ }^{3}$ Northern Research Institute of Forestry, Nikitov str, 13, Archangelsk, 163062, Russian Federation
}

\section{Abstract}

Thinning of young forests attracts the attention of scientists despite the long-term commercial effect. However, these researches are scarce. Therefore, it is important to study experiments with a long history. The aim of our study is to investigate the impact of thinning carried out in young pine/birch boreal forests on stand formation, natural regeneration, ground cover and properties of the soil layers in stands.

We investigated three types of thinning in young pine/birch forests. In one plot of the initial stand, thinning was performed in two stages with a time interval of 27 years; in the first stage, thinning intensity was $75 \%$ of stems, while in the second stage, thinning intensity was $30 \%$. In two other plots, thinning was performed in one stage at a stand age of 13 years, with thinning intensities of 76 and $84 \%$. At the stand age of 72 years (2017), integrated studies of the silvicultural and ecological states were carried out.

All thinned plots had developed into pure pine stands with $28-53 \%$ thicker stems, $12-18 \%$ higher trees and a growing stock 55-92\% higher compared to the un-thinned reference stand. The most pronounced differences were observed for Option 1. With thinning, forest type changed to red whortleberry type, while the un-thinned reference site developed into a blueberry type forest.

Thinning in young pine/birch stands results in the formation of pure pine stands. The associated modification of environmental properties changed the composition and density of the ground cover and some properties of the upper soil layers. Two-stage thinning had the least impacts; this approach can be used to produce stands with high commercial value. It is especially recommended for young pine/birch forests in the northern taiga.

\section{KeY WORDS}

strip cutting method, boreal forest, ecological interactions, forest understory vegetation, soil properties 


\section{INTRODUCTION}

To determine the impacts of thinning on stand growth and formation, it is necessary to carry out long-term experiments, as the use of short-term thinning tests often results in contradictive conclusions and unreliable results (Yuodvalkis et al. 1988). In the European north of Russia, such large-scale research plots have been established by the Northern Forestry Research Institute (Chibisov et al. 2004, 2007, 2011).

Thinning of forests for wood production is of increasing economic significance in Russia and around the world (Trubin et al. 2000; Emmingham 2010). However, there is no consensus on stand productivity increase as a result of thinning, although several studies have shown increase in diameter, height, crop size and other stand properties' improvement as the results of thinning (Sennov 1977, 1984; Chibisov et al. 2004, 2011; Belyaeva 2010; Mäkinen 2004; Del Rio et al. 2008, 2017). Previous studies have shown that thinning has positive effects on stand resistance to adverse weather and biological conditions, reduces mortality, improves stand formation and composition, increases productivity per area unit and accelerates tree growth (Davydov 1971; Lositsky and Chuenkov 1980; Hilt and Dale 1989; Boncina et al. 2007).

Thinning also has an impact on the lower forest layers (natural regeneration, species composition, vegetation abundance in the ground cover, topsoil layers). In the southern taiga, changes in the upper soil layer properties, in particular in terms of thickness, humus content, soil reaction, have been observed, with various impacts on the forest stands (Sennov 1977, 1984).

The modification of lower forest layers, as a result of thinning, has been studied widely (Burova and Feklistov 2007; Feklistov and Torbik 2011; Levkovskaya and Sarnatsky 2013; Solgi et al. 2015; Cambi et al. 2015; Naghdi et al. 2016; Dymov 2017). However, such studies mainly investigated the strip thinning carried out with heavy equipment, and several studies have focused on soil compaction and tracks as a result of forest management (Murphy et al. 2004; Page-Dumroese et al. 2009).

The positive value of thinning in young stands for the dynamics and tree quality was noted by Rytter and Werner (2007), Swift et al. (2016) and J. Novàk et al. (2017). Thinning may also increase stand biodiversity and ecosystem service values (Ahnlund and Ulvcrona et al. 2017), but reduce carbon stocks (D'Amore et al. 2015). According to Cameron (2002), non-commercial early thinning is a long-term investment in the quality and quantity of forest stands without loss of their survivability, therefore representing a practical approach. Thinning in young stands is important for early forestry (Rytter and Werner 2007) and cause intensive farming (Marcovskii and Rodionov 2018). In this sense, it is important to not only investigate the commercial potential of thinning, but to also assess its compliance with silvicultural and ecological requirements, follow-on reforestation opportunities and stand stability. In this context, the aim of our study is to investigate the impact of thinning carried out in young pine/birch boreal forests on stand formation, natural regeneration, ground cover and properties of the topsoil layers in stands in the northern taiga subzone.

\section{Material AND Methods}

The study was carried out in permanent experimental sites established in 1959 by the Arkhangelsk Forests and Forest Chemistry Institute (now - Northern Forestry Research Institute) at the Northern Country Forest Division of the Obozersk Forest Division in the Arkhangelsk Region. The study area is located in the boreal forest (northern taiga subzone: $63^{\circ} 28^{\prime} 46.8^{\prime \prime} \mathrm{N} ; 40^{\circ} 19^{\prime} 52.9^{\prime} \mathrm{E}$ ) (Fig. 1). In young pine/birch forests (13 years old) of the blueberry/red whortleberry type with a $60 \%$ pine and $40 \%$ birch and sporadic aspens composition, different types of thinning were performed. 13-year initial planting was represented by pine-birch young stand of blueberry-cowberry forest type. In the year of thinning, the height of pine was $2.9 \mathrm{~m}$, diameter $1.5 \mathrm{~cm}$, number of trees per $1 \mathrm{ha}-3480$, for birch $-2.4 \mathrm{~m}, 1.2 \mathrm{~cm}$ and 1070 trees, respectively. Thinning was carried out using no strip cutting method with foliage tree removal.

In one part of the initial forest stand (Option 1), thinning was performed in two stages with a time interval of 27 years; in the first stage, the thinning rate was $75 \%$ of total trees (1,680 trees per 1 ha remained), while in the second stage, a thinning rate of $30 \%$ was adopted. At present, this site contains 837 trees per 1 ha. In the other sites (Options 2 and 3), thinning was carried out in one stage. Stand age was 13 years, with thinning rates of $76 \%$ and $84 \%$, respectively (1,040 and 744 trees, re- 


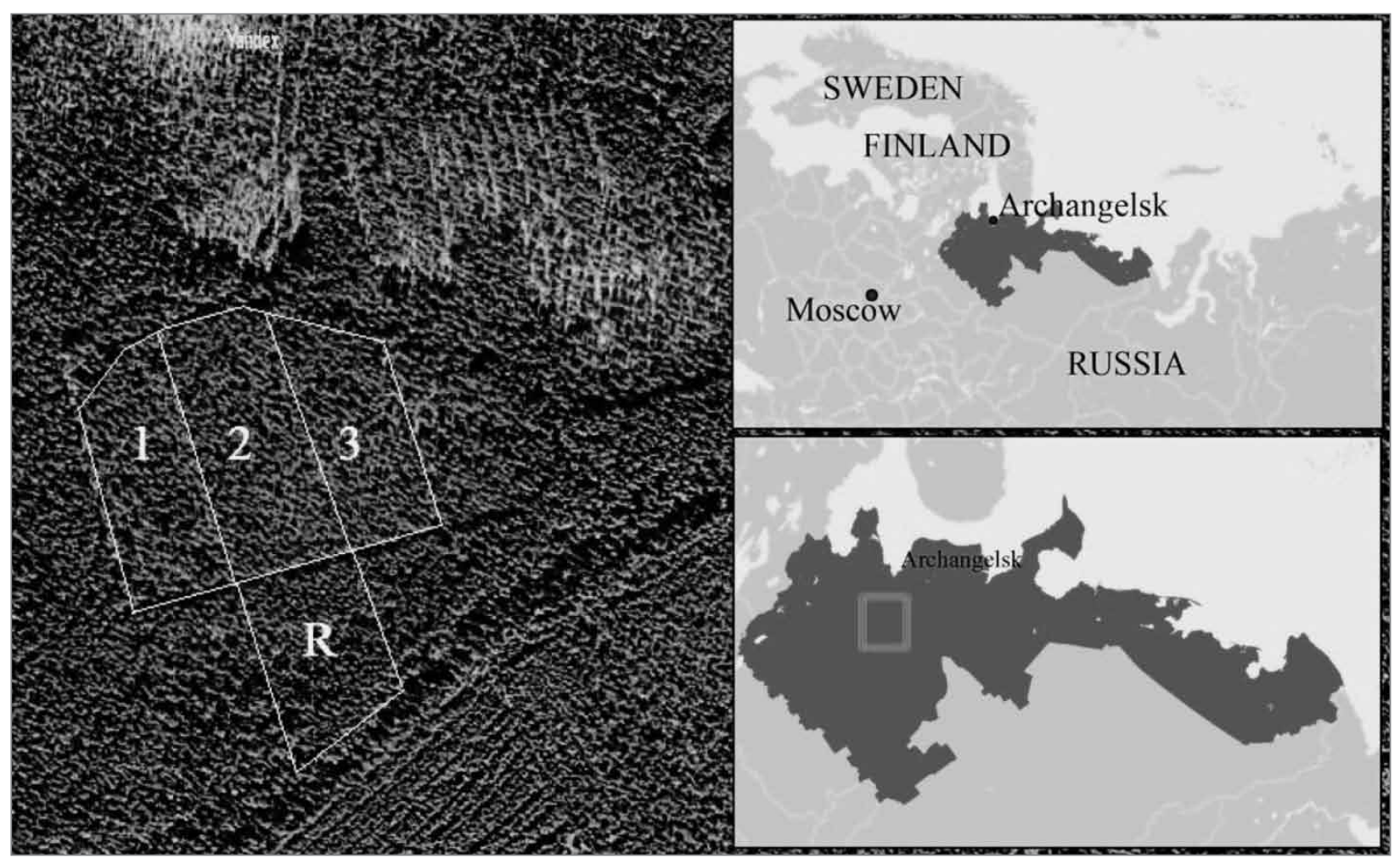

Figure 1. Location of the studied area (Archangelsk, Northern Russia) with specified experimental $(1,2,3)$ and reference (R) option

spectively, remained). Forest densities are currently 894 and 596 trees/ha, respectively.

In the thinning of the 13-year-old stand, foliage trees were first cut with an axe and left in the site. In the 40-year-old stand, stunted trees were selected and cut using a chain saw; the lops and tops were cut and left in the site. Stands (total $41 \mathrm{~m}^{3} / \mathrm{ha}$ ) were bucked and prepared for use as firewood.

As reference, non-thinned stands were used, with naturally formed pine/birch communities ( $80 \%$ pine, $20 \%$ birch). In each site, we established a plot of 0.25 ha. Soil type was Folic Albic Podzol (Arenic). To investigate the thinning of 72-year-old stands (2017), integrated examination of their silvicultural and environmental states was carried out.

In each experimental plot, tree diameter at a breast height was measured for all trees. Average tree height was determined with the help of a height chart. For this purpose, the heights of 12-15 trees with different taxational diameters were measured with an accuracy of $0.1 \mathrm{~m}$. For standing crop calculation, volume tables gen- erally accepted for the study region were used (Forest Mensuration Handbook 2012). Average annual height and diameter growth as well as stock addition were also calculated. Comparison of tree quantities by diameter was performed using natural diameter classes; for this purpose, tree diameter was expressed in percentage of average stand diameter.

To account for natural regeneration (undergrowth and brushwood), in the centre of each experimental site, 20 control plots of $2 \times 2 \mathrm{~m}$ were established. Undergrowth inventory was performed in terms of species, size and vitality determination. The understorey was divided into small (height by $0.5 \mathrm{~m})$, intermediate $(0.6-1.5 \mathrm{~m}$ height) and large $(>1.5 \mathrm{~m}$ height, by $6 \mathrm{~cm}$ diameter on height of $1.3 \mathrm{~m})$ as well as into vital, non-vital and dead.

In each experimental site, the living ground cover was investigated in 20 subplots of $1 \times 1 \mathrm{~m}$. Species composition, projective cover degree, average, phenological stage, vitality, comprising grass/dwarf shrub and moss/ lichen layers were determined. Vascular plants were identified after S.K. Cherepanov (1995). 
To investigate the soil, within each experimental site, 30 small trenches were laid out in the space between the tree tops (120 in total). The forest floor (O) was sampled using a sample frame $\left(100 \mathrm{~cm}^{2}\right)$; sample thickness was measured from four sides with an accuracy of $1 \mathrm{~cm}$. The average thickness of the E horizon was measured, and soil samples were taken using a metal soil-sample barrel for the determination of soil density of the $\mathrm{O}$ and $\mathrm{E}$ horizons. In the $\mathrm{O}$ horizon, bone-dry humidity $(\mathrm{t} / \mathrm{ha})$ was determined.

Mobile phosphorus and potassium compounds, actual acidity and exchange acidity (by $\mathrm{KCl}$ extract) were determined using a potentiometer. Losses on incineration at $800^{\circ} \mathrm{C}$ and soil organic carbon content (\%) in the E horizon were determined using a generally accepted method. All analyses were performed in duplicate.

The permutation test was used to determine the significance of differences between the mean values for soil parameters. Jaccard index (Eq. 1) was used to compare the similarity of biodiversity of sample sets. Data analysis was conducted using R 3.4.2 (R Core Team 2017) and the library «vegan» package (Oksanen et al.

Table 1. Stand description and taxational parameters by test options

\begin{tabular}{|c|c|c|c|c|c|c|c|c|c|c|c|c|c|}
\hline \multirow[b]{2}{*}{ 苛 } & \multirow[b]{2}{*}{ 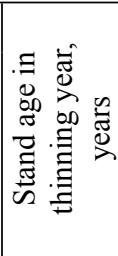 } & \multirow[b]{2}{*}{ 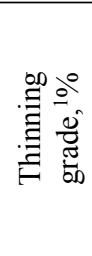 } & \multicolumn{7}{|c|}{ Average data on observation year } & \multicolumn{3}{|c|}{ Average annual growth } & \multirow{2}{*}{ 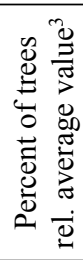 } \\
\hline & & & 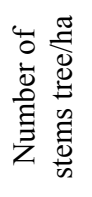 & 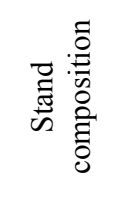 & $\begin{array}{l}\frac{\tilde{U}}{0} \\
\text { है } \\
\text { की }\end{array}$ & 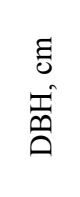 & $\begin{array}{l}\Xi \\
\pm\end{array}$ & 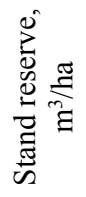 & 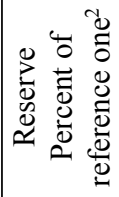 & 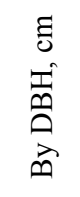 & 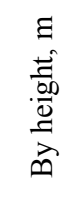 & 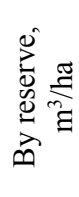 & \\
\hline \multirow{2}{*}{. } & 13 & 75 & \multirow{2}{*}{837} & \multirow{2}{*}{$100 \mathrm{C}$} & \multirow{2}{*}{$\mathrm{C}$} & \multirow{2}{*}{23.6} & \multirow{2}{*}{21.5} & \multirow{2}{*}{374} & \multirow{2}{*}{$\frac{191.8}{148.4}$} & \multirow{2}{*}{0.33} & \multirow{2}{*}{0.30} & \multirow{2}{*}{5.19} & \multirow{2}{*}{$\frac{50.0}{50.0}$} \\
\hline & 40 & 30 & & & & & & & & & & & \\
\hline مै & 13 & 76 & 894 & $100 \mathrm{C}$ & $\mathrm{C}$ & 22.1 & 208 & 329 & $\frac{168.7}{130.6}$ & 0.31 & 0.29 & 4.57 & $\underline{50.9}$ \\
\hline m & 13 & 84 & 596 & $100 \mathrm{C}$ & $\mathrm{C}$ & 25.6 & 20.5 & 303 & $\frac{155.4}{120.2}$ & 0.36 & 0.29 & 4.21 & $\frac{52.4}{47.6}$ \\
\hline \multirow{2}{*}{ 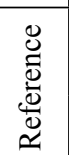 } & \multirow{2}{*}{-} & \multirow{2}{*}{-} & \multirow{2}{*}{1796} & \multirow{2}{*}{$77 \mathrm{C} 235$} & $\mathrm{C}$ & 16.7 & 18.3 & 195 & - & 0.23 & 0.25 & 2.71 & $\underline{51.6}$ \\
\hline & & & & & Б & 11.3 & 16.1 & 57 & - & - & - & - & - \\
\hline
\end{tabular}

Note: 1 - for Option 1 at the age of 40 years, cut $\%$ of volume; 2 - in numerator - relative pine volume, in denominator - relative total volume of reference stand; 3 - in numerator - below average, in denominator - over average value; $\mathrm{P}$ - pine-tree (Pinus sylvestris (L.), B - birch-tree (Betula pendula (Roth), $\mathrm{DBH}$ - diameter at breast height, $\mathrm{H}$ - height.
2013). The Jaccard (Rosenberg 2012) index was calculated as follows:

$$
\mathrm{J}(\mathrm{A}, \mathrm{B})=\mathrm{C} /(\mathrm{A}+\mathrm{B}-\mathrm{C})
$$

where:
A, B - number of species in Options A and B;
$\mathrm{C}-$ number of species in Options A and B in total.

\section{Results}

Forest stand. Taxational parameters of forest stands are given in Table 1.

Thinning in young forests results in significant benefits due to a higher pine tree diameter, increased growth rates and a higher stock volume. At a stand age of 72 years, in all the options of pine/birch forests thinned when young, pine tree diameter was $23 \%-53 \%$, height $12 \%-18 \%$ and standing crop $55 \%-92 \%$ higher than in reference forest stands. The most evident differences were observed for Option 1, where thinning was performed in two stages. The standing crop was about 2 times higher than that of the reference stands. 

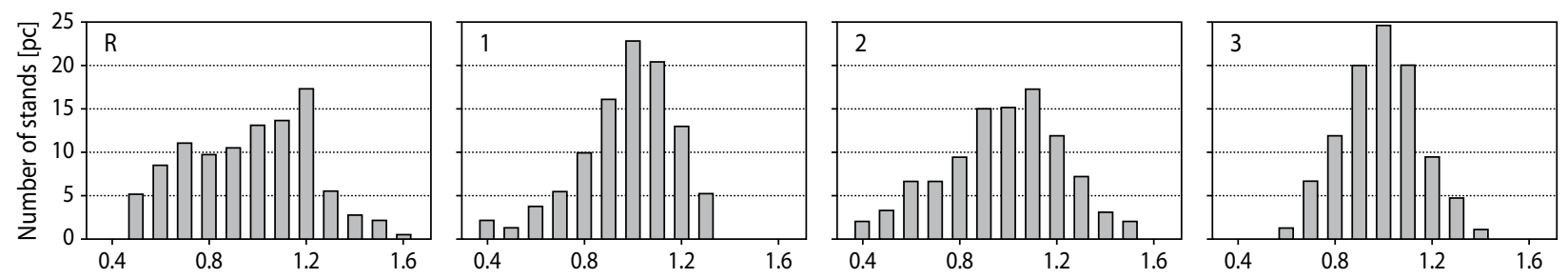

Figure 2. Pine tree stem distribution by natural diameter classes

In the reference forest stand, stand composition ( $80 \%$ pine, $20 \%$ birch) was optimal in terms of benefits for forestry; however, the productivity of this stand was significantly lower than that of pure pine stands formed as a result of improvement cutting, making this stand less economically viable.

Pine-tree stem distribution in terms of diameter in thinned forest stands differed from that of the reference forest stand. Differences were observed for distribution uniformity (Fig. 2), with a higher number of large trees (above average diameter). As a result of the two-stage thinning (Option 1), dextrality in stem distribution by diameter class was observed, with maximum tree number registered in Class 1 (1.0) and a distribution series reduction of 0.6 to 1.4. In Option 3 (single intensive cutting of $84 \%$ of trees), stem distribution was symmetric, and the natural thickness variation range was narrow at higher excess value. Maximum stem number was registered in Class 1.0.

In natural forest stands and in the experimental plots, the understorey was dominated by Picea obovata (Karst.). An undergrowth of Pinus sylvestris (L.) (the main crown cover species) was only present in options with one-stage cutting of $76 \%$ and $84 \%$ of young trees. Thinning results in forest cleaning, and subsequently, in aspen and occasional larch-tree undergrowth development (Tab. 2).
The amounts of coniferous species in the undergrowth only slightly varied and ranged from 2.9 to 3.8 thousand trees/ha. According to the Regulations on Reforestation in the Northern Taiga of the European Part of the Russian Federation, large-sized undergrowth consists of 1.2 to 2.8 thousand trees/ha. In the reference forest stand and in Options 1 and 3, spruce and pine undergrowth ensured natural regeneration after thinning, provided that harvesting techniques with undergrowth protection are used. Permutation test showed no thinning effect on the undergrowth of naturally regenerated forest sites $(p=0.48)$.

In all experimental plots, small ( $0.5 \mathrm{~m}$ high) viable undergrowth was present, mainly consisting of the species Salix caprea L., Rosa acicularis Lindl., Sorbus aucuparia L.; in the reference plot, Juniperus communis L. (1,375 trees/ha) occurred. Undergrowth species were distributed non-uniformly across the plot, unviable and bone-dry undergrowth occurred occasionally. The greatest amount and species diversity of undergrowth was observed in the reference stand with 6,125 trees/ha. Undergrowth was mostly represented by Rosa acicularis and Sorbus aucuparia and occurred in numbers of 500-3,000 trees/ha in the experimental stands. Two-stage thinning resulted in up to 3,000 trees/ha in the understorey.

Live ground cover is an integrated part of the forest biocenosis and characterizes the forest site, directly

Table 2. Number of viable undergrowth species (trees/ha) of all size classes in the experimental plots and the reference plot

\begin{tabular}{|c|c|c|c|c|c|c|c|c|c|}
\hline \multirow{2}{*}{ Option } & \multirow{2}{*}{$\mathrm{P}$} & \multicolumn{2}{|c|}{$\mathrm{S}$} & \multirow{2}{*}{$\mathrm{L}$} & \multirow{2}{*}{ B } & \multirow{2}{*}{ As } & \multicolumn{2}{|c|}{ Total } & \multirow{2}{*}{ Composition } \\
\hline & & Tr./ha & $\% *$ & & & & Tr./ha & $\% *$ & \\
\hline Option 1 & 0 & 3750 & 131 & 0 & 2125 & 500 & 6375 & 189 & 6S3B1As \\
\hline Option 2 & 250 & 1625 & 57 & 0 & 250 & 375 & 2500 & 74 & 7S1P1B1As \\
\hline Option 3 & 125 & 3125 & 108 & 125 & 500 & 750 & 4500 & 133 & $7 \mathrm{~S} 1 \mathrm{~B} 2 \mathrm{As}+\mathrm{P}+\mathrm{L}$ \\
\hline Reference & 0 & 2875 & 100 & 0 & 500 & 0 & 3375 & 100 & 9S1B \\
\hline
\end{tabular}

*-value relatively to the reference; $\mathrm{P}$ - pine, $\mathrm{S}$ - spruce, $\mathrm{L}$ - larch, $\mathrm{B}$ - birch, $\mathrm{As}$ - aspen. 
impacts soil formation processes and provides natural regeneration of the main tree species.

The initial forest type in our study was the blueberry/red whortleberry type. As a result of forest thinning via improvement cutting, the forest type gradually changed to the pine-tree/red whortleberry type, while in the reference plot, a blueberry type forest was formed. With forest stand thinning, the red whortleberry projective cover increased, while the blueberry protective cover decreased (Fig. 3).

The main species making up the ground cover were similar for all options (Tab. 3). However, in the thinned

Table 3. Projective cover and occurrence of ground cover species in the different options

\begin{tabular}{|c|c|c|c|c|c|c|c|c|}
\hline \multirow{2}{*}{ Species } & \multicolumn{2}{|c|}{ Option 1} & \multicolumn{2}{|c|}{ Option 2} & \multicolumn{2}{|c|}{ Option 3} & \multicolumn{2}{|c|}{ Reference } \\
\hline & $\mathrm{PC}$ & $\mathrm{O}$ & $\mathrm{PC}$ & $\mathrm{O}$ & $\mathrm{PC}$ & $\mathrm{O}$ & $\mathrm{PC}$ & $\mathrm{O}$ \\
\hline \multicolumn{9}{|c|}{ Dwarf shrub } \\
\hline Vaccinium vitis-idaea L. & $47.6 / 168^{*}$ & 100 & $39.5 / 139$ & 100 & $57.3 / 202$ & 100 & $28.4 / 100$ & 100 \\
\hline Vaccinium uliginosum L. & $0.05 /-$ & 5 & - & - & $0.05 /-$ & 5 & - & - \\
\hline Vaccinium myrtillus L. & $35.9 / 60$ & 100 & $26.5 / 44$ & 100 & $24.4 / 47$ & 100 & $60.0 / 100$ & 100 \\
\hline \multicolumn{9}{|c|}{ Herb species } \\
\hline Ledum polustre L. & - & - & - & - & - & - & - & - \\
\hline Cirsium heterophyllum (L.) Hill & - & - & - & - & $0.05 /-$ & 5 & - & - \\
\hline Calluna vulgaris (L.) Hill & $2.2 /-$ & 5 & - & - & - & - & - & - \\
\hline Empetrum nigrum L. & $2.2 /-$ & 30 & $0.3 /-$ & 10 & $3.7 /-$ & 45 & - & - \\
\hline Pyrola rotundifolia L. & - & - & - & - & $0.3 /-$ & 5 & - & - \\
\hline Solidago virgaurea L. & $0.2 / 18$ & 15 & $0.2 / 18$ & 10 & $0.05 / 5$ & 5 & $1.1 / 100$ & 60 \\
\hline Chamaenerion angustifolium (L.) Hill & $0.7 / 140$ & 40 & $0.5 / 100$ & 40 & $0.9 / 180$ & 65 & $0.5 / 100$ & 40 \\
\hline Antennaria dioica (L.) Gaertn. & - & - & $0.3 /-$ & 5 & $0.1 /-$ & 5 & - & - \\
\hline Linnae aborealis L. & $1.0 / 48$ & 5 & $5.8 / 276$ & 20 & - & - & $2.1 / 100$ & 15 \\
\hline Majanthemum bifolium (L.) F.W. Schmidt & - & - & - & - & - & - & $0.2 / 100$ & 10 \\
\hline Carex sylvaticaHuds. & - & - & $0.3 /-$ & 20 & $1.7 /-$ & 30 & - & - \\
\hline Lycopodium annotinum L. & $3.6 /-$ & 30 & 9.9/- & 60 & $7.5 /-$ & 65 & - & - \\
\hline Lycopodium complanatum L. & $5.3 /-$ & 40 & $9.5 /-$ & 55 & $4.0 /-$ & 30 & - & - \\
\hline Trientalis europaea L. & - & - & $0.05 / 8$ & 5 & - & - & $0.6 / 100$ & 20 \\
\hline Lathyrus vernus (L.) Bernh. & $0.05 /-$ & 5 & - & - & - & - & - & - \\
\hline Deschampsia cespitosa L. & $3.3 / 46$ & 40 & $6.6 / 92$ & 75 & $0.3 / 4$ & 15 & $7.2 / 100$ & 85 \\
\hline Hieracium murorum L. & - & - & - & - & $0.3 / 150$ & 25 & $0.2 / 100$ & 10 \\
\hline Orchis maculate L. & - & - & $1.0 / 250$ & 15 & - & - & $0.4 / 100$ & 25 \\
\hline \multicolumn{9}{|c|}{ Mosses and lichens } \\
\hline Cetraria islandica (L.) Ach. & - & - & $0.1 /-$ & 10 & - & - & - & - \\
\hline Cladonia alpestris (L.) Rabenh & - & - & $0.1 /-$ & 10 & $0.1 /-$ & 5 & - & - \\
\hline Cladonia rangiferina (L.) F.H.Wigg. & - & - & $3.5 /-$ & 70 & $2.4 /-$ & 65 & - & - \\
\hline Dicranum polysetum Sw. & $12.0 / 73$ & 90 & $17.7 / 107$ & 95 & $29.1 / 176$ & 95 & $16.5 / 100$ & 95 \\
\hline Phytidiadelphus triguetrus (Hedw.) Warnst. & $4.3 / 42$ & 45 & $3.9 / 41$ & 30 & $2.6 / 27$ & 35 & $9.5 / 100$ & 65 \\
\hline Pleurozium schreberi (Willd. ex Brid.) Mitt. & $72.5 / 147$ & 100 & $67.7 / 137$ & 100 & $58.5 / 119$ & 100 & $49.3 / 100$ & 100 \\
\hline Polytrichum commune Hedw. & $1.3 / 37$ & 10 & $2.1 / 60$ & 50 & $1.0 / 29$ & 40 & $3.5 / 100$ & 60 \\
\hline Ptilium-crista-castrensis Hedw. & $10.0 / 435$ & 35 & $5.0 / 217$ & 50 & $6.4 / 278$ & 40 & $2.3 / 100$ & 65 \\
\hline
\end{tabular}

$*_{-}$in $\%$ to reference; $\mathrm{PC}$ - projective cover in $\%, \mathrm{O}$ - occurrence in $\%$. 


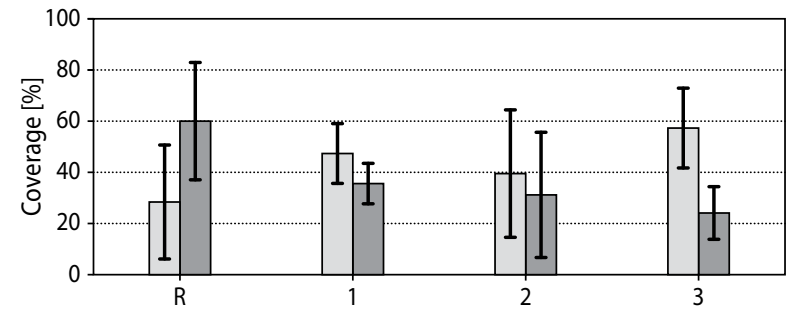

Figure 3. Average coverage of V. myrtillus (in dark grey) and V. vitis-idaea (in light grey) in the experimental plots with standard deviation error bar

forest stands, new plant species appeared, for example, Calluna vulgaris (L.) Hill, Lycopodium annotinum L.; Lycopodium complanatum L.; Lathyrusvernus (L.) Bernh. At the same time, in comparison with the reference forest stand, the projective cover the grass/dwarf shrub storey, with species such as Solidago virgaurea L., Trientalis europaea L., Deschampsia cespitosa L. was reduced, and some species disappeared ( $M a-$ janthemum bifolium (L.) F.W. Schmidt).

In the moss/lichen storey, the modifications were less pronounced. In all the thinned experimental plots, the projective cover of moss species such as Phytidiadelphus triguetrus (Hedw.) Warnst. and Polytrichum commune Hedw. was reduced, while the species Ptilium crista-castrensis Hedw. and Pleurozium schreberi (Willd. exBrid.) Mitt. were increased in comparison with the reference forest stand.
As a result of improvement cutting via single-stage thinning, lichen species appeared in the subordinate vegetation composition: (Cetraria islandica (L.) Ach., Cladonia alpestris (L.) Rabenh, Cladonia rangiferi$n a$ (L.) F.H. Wigg.). In the reference forest stand and in Option 1, lichen species were not observed.

The total number of ground cover species changed due to forest stand thinning. Option 3 showed the highest species richness (14) in the grass/dwarf shrub storey (14), as a result of one-stage thinning with an intensity of $84 \%$. Species richness in the experimental plots subjected to one- and two-stage thinning (75\% intensity; Options 1 and 2) was similar (12), while the reference plot showed a species number of 10 .

The floristic composition was examined for all thinning plots and compared to that of the reference site. The most significant differences between the thinned plots and the reference site were observed for Option 1 (two-stage thinning of $75 \%$ intensity) and Option 3 (one-stage thinning of $84 \%$ intensity); the Jaccard index was $37.5 \%$ and $33.3 \%$, respectively. One-stage thinning of $76 \%$ intensity in young forests did not result in a significant modification of grass/ dwarf shrub storey species diversity (Jaccard index $=$ $57 \%$ ). All thinned forest stands differed in terms of specific species comprising their grass/dwarf shrub storeys (Jaccard index of 50\% and less). For the moss/ lichen storey, the Jaccard index was above 50\%, that

Table 4. Statistical data on physical properties of $\mathrm{O}$ and $\mathrm{E}$ horizons within thinned test plots, in comparison with the reference plot

\begin{tabular}{|c|c|c|c|c|}
\hline Index & Option 1 & Option 2 & Option 3 & Reference \\
\hline \multicolumn{5}{|c|}{ O thickness, cm } \\
\hline $\mathrm{X} \pm \mathrm{m}_{\mathrm{x}}$ & $4.14 \pm 0.17$ & $3.95 \pm 0.17$ & $3.45 \pm 0.19$ & $3.38 \pm 0.16$ \\
\hline P-value & $<0.05$ & $<0.05$ & 0.77 & - \\
\hline \multicolumn{5}{|c|}{ Bulk density for $\mathrm{O}, \mathrm{g} / \mathrm{cm}^{3}$} \\
\hline $\mathrm{X} \pm \mathrm{m}_{\mathrm{x}}$ & $0.14 \pm 0.01$ & $0.14 \pm 0.01$ & $0.10 \pm 0.01$ & $0.12 \pm 0.01$ \\
\hline P-value & 0.05 & 0.06 & 0.10 & - \\
\hline \multicolumn{5}{|c|}{ O reserve, $\mathrm{t} / \mathrm{ha}$} \\
\hline $\mathrm{X} \pm \mathrm{m}_{\mathrm{x}}$ & $58.38 \pm 4.14$ & $55.85 \pm 4.45$ & $34.59 \pm 2.94$ & $40.17 \pm 3.16$ \\
\hline P-value & $<0.05$ & $<0.05$ & 0.20 & - \\
\hline \multicolumn{5}{|c|}{ E thickness, cm } \\
\hline $\mathrm{X} \pm \mathrm{m}_{\mathrm{x}}$ & $7.25 \pm 0.73$ & $9.50 \pm 0.68$ & $8.64 \pm 0.62$ & $6.25 \pm 0.60$ \\
\hline P-value & 0.34 & $<0.05$ & $<0.05$ & - \\
\hline
\end{tabular}

Note: $\mathrm{X} \pm \mathrm{mx}$ - mean value and standard error of mean 
is, thinning had no significant impact on the moss/lichen community.

Thinning significantly impacted soil physical properties such as soil thickness of $\mathrm{O}$ and $\mathrm{E}$ horizons as well as soil density of the $\mathrm{O}$, but had no effect on the soil density of the $\mathrm{E}$ (Tab. 4).

The $\mathrm{O}$ thickness was most significantly influenced by environmental factors as a result of thinning $(\mathrm{y}=33.2 \%)$. Thinning impact on density of soil structure and $\mathrm{O}$ reserve is $13 \%-14 \%$.

In comparison with the reference forest stand (Tab. 5), the $\mathrm{O}$ was thicker in stands of Options 1 and 2. At a higher cutting intensity (84\%), O layer thickness in Option 3 stand significantly differed from that of Options 1 and 2 and was similar to that of the non-thinned reference plot. In all experimental plots, soil density of the $\mathrm{O}$ ranged from 0.10 to $0.14 \mathrm{~g} / \mathrm{cm} 3$. The same tendency was observed for layer thickness. In pine forests of Options 1 and 2, soil density of the $\mathrm{O}$ was higher, but without significant differences to the reference stands (Tab. 5). Density of the $\mathrm{O}$ in Option 3 was lower when compared to that of Option 1 and 2 and the reference stand.

Table 5. Chemical properties of the O layer in the experimental plots

\begin{tabular}{|l|c|c|c|c|c|c|}
\hline \multirow{2}{*}{ Option } & \multicolumn{2}{|c|}{ Incineration loss } & \multicolumn{2}{|c|}{$\mathrm{pH}_{\mathrm{H} 20}$} & \multicolumn{2}{|c|}{$\mathrm{pH}_{\mathrm{KCl}}$} \\
\cline { 2 - 7 } & $\%$ & $\%^{*}$ & $\mathrm{pH}$ & $\% *$ & $\mathrm{pH}$ & $\% *$ \\
\hline Option 1 & 80.5 & 128.6 & 4.4 & 95.7 & 3.3 & 94.3 \\
\hline Option 2 & 94.8 & 151.4 & 4.6 & 100 & 3.3 & 94.3 \\
\hline Option 3 & 94.2 & 150.5 & 4.5 & 97.8 & 3.5 & 100 \\
\hline Reference & 62.6 & 100 & 4.6 & 100 & 3.5 & 100 \\
\hline
\end{tabular}

* - relatively to the reference stand value

The average value of the $\mathrm{O}$ reserve varied from 34.6 to $58.4 \mathrm{t} / \mathrm{ha}$ in the experimental plots and was $40.2 \mathrm{t} / \mathrm{ha}$ in the reference site. The maximum value was observed for the $\mathrm{O}$ in the pine stands of Options 1 and 2. This value did not depend on the number of thinning stages and greatly differed from that of the reference stand (see Tab. 5). In Option 3, the O reserve was lower than in the denser stands of Options 1 and 2, mainly as a result of the lower layer thickness and soil density.

In the thinned stands, losses of the $\mathrm{O}$ via combustion were $30 \%-50 \%$ higher in comparison with the reference stand (Tab. 6). Therefore, organic matter accumulation mostly depends on the thinning method (onestage or two-stage thinning) rather than on the thinning intensity. Gradual removal of trees results in lower organic matter accumulation. Layer $\mathrm{O}$ reaction to changes in stocking in a forming stand remains quite persistent.

The impact of improvement cutting in young forests on the physical properties of the mineral part of the subsoil layer (E horizon) was less evident than that on the O horizon. Soil density of the E layer in the experimental plots varied between 1.23 and $1.28 \mathrm{~g} / \mathrm{cm}^{3}$, with a total porosity of $50.8 \%$ to $52.7 \%$.

However, environmental and coenotic factors in pine stands of different stand densities had significant impacts on $\mathrm{E}$ layer thickness. In the stand subjected to one-stage removal at the age of 13 years, the $E$ layer was significantly thicker when compared to that of the reference stand (see Tab. 5). After gradual (two-stage) cutting of 13- and 40-year-old trees (Option 1), E layer thickness was similar to that of the reference stand $(p>0.05)$. In this approach, podsolization was less intense than in one-stage thinning.

In the thinned stands, the soil organic carbon content of the E layer (Tab. 7) was 2-3 times higher than that in the reference stand. Soil acidity variation was insignificant, while the nutrient content (mobile phosphorous and potassium compounds) was slightly higher than in the stands where $75 \%$ of the young trees were cut (Tab. 7).

Table 6. Chemical properties of the soil E layer in the experimental plots

\begin{tabular}{|l|c|c|c|c|c|c|c|c|c|c|c|c|}
\hline \multirow{2}{*}{ Option } & \multicolumn{2}{|c|}{ Incineration loss } & \multicolumn{2}{c|}{ Organic carbon } & \multicolumn{2}{c|}{$\mathrm{pH}_{\mathrm{H} 20}$} & \multicolumn{2}{c|}{$\mathrm{pH}_{\mathrm{KCl}}$} & \multicolumn{2}{c|}{$\mathrm{P}_{2} \mathrm{O}$ content } & \multicolumn{2}{c|}{$\mathrm{K}_{2} \mathrm{O}$ content } \\
\cline { 2 - 13 } & $\%$ & $\% *$ & $\%$ & $\% *$ & $\mathrm{pH}$ & $\%^{*}$ & $\mathrm{pH}$ & $\% *$ & $\mathrm{mg} / \mathrm{kg}$ & $\% *$ & $\mathrm{mg} / \mathrm{kg}$ & $\% *$ \\
\hline Option 1 & 2.5 & 156.3 & 1.1 & 366.7 & 4.4 & 96.7 & 3.7 & 100 & 8.6 & 111.7 & 24.5 & 108.9 \\
\hline Option 2 & 2.6 & 162.5 & 0.7 & 233.3 & 4.5 & 97.8 & 3.9 & 105.4 & 7.9 & 102.5 & 24.5 & 108.9 \\
\hline Option 3 & 1.5 & 93.8 & 0.8 & 266.7 & 4.6 & 100 & 3.9 & 105.4 & 5.5 & 71.4 & 22.0 & 97.8 \\
\hline Reference & 1.6 & 100 & 0.3 & 100 & 4.6 & 100 & 3.7 & 100 & 7.7 & 100 & 22.5 & 100 \\
\hline
\end{tabular}

* - relatively to the reference stand value 
Table 7. Chemical properties of the soil E layer in the experimental plots

\begin{tabular}{|l|c|c|c|c|c|c|c|c|c|c|c|c|}
\hline \multirow{2}{*}{ Option } & \multicolumn{2}{|c|}{ Incineration loss } & \multicolumn{2}{c|}{ Organic carbon } & \multicolumn{2}{c|}{$\mathrm{pH}_{\mathrm{H} 20}$} & \multicolumn{2}{|c|}{$\mathrm{pH}_{\mathrm{KCl}}$} & \multicolumn{2}{|c|}{$\mathrm{P}_{2} \mathrm{O}$ content } & \multicolumn{2}{c|}{$\mathrm{K}_{2} \mathrm{O}$ content } \\
\cline { 2 - 14 } & $\%$ & $\%^{*}$ & $\%$ & $\%^{*}$ & $\mathrm{pH}$ & $\%^{*}$ & $\mathrm{pH}$ & $\%^{*}$ & $\mathrm{mg} / \mathrm{kg}$ & $\% *$ & $\mathrm{mg} / \mathrm{kg}$ & $\% *$ \\
\hline Option 1 & 2.5 & 156.3 & 1.1 & 366.7 & 4.4 & 96.7 & 3.7 & 100 & 8.6 & 111.7 & 24.5 & 108.9 \\
\hline Option 2 & 2.6 & 162.5 & 0.7 & 233.3 & 4.5 & 97.8 & 3.9 & 105.4 & 7.9 & 102.5 & 24.5 & 108.9 \\
\hline Option 3 & 1.5 & 93.8 & 0.8 & 266.7 & 4.6 & 100 & 3.9 & 105.4 & 5.5 & 71.4 & 22.0 & 97.8 \\
\hline Reference & 1.6 & 100 & 0.3 & 100 & 4.6 & 100 & 3.7 & 100 & 7.7 & 100 & 22.5 & 100 \\
\hline
\end{tabular}

* - relatively to the reference stand value

In the pine forest stands of Options 1 and 2, mobile phosphorus and potassium compound concentrations in the $\mathrm{E}$ layer were higher than in the reference stand and in Option 3. After thinning with an intensity of $84 \%$, the nutrient content in the E layer was lower than that of the reference site, especially in terms of phosphate (by $29 \%$ ).

\section{Discussion}

Thinning efficiency depends not only on the quality and quantity of the forest stands, but also on ecological components and on the resistance of stands to various environmental factors. In this context, the final aim is to develop the best combination of different environmental characteristics related to forest stand growth and development in whole (Sennov 1977, 1984; Formanek and Vranova 2003; Ares 2005). As a criteria, quality category upgrading, stand volume increase and other taxational characteristics can be accepted (Saramiaki 1993; Lowell 2012). Our results prove the hypothesis that stand density can be reduced (down to 600-900 trees per 1 ha at the age of 72 years) without any damage to timber volume. This conclusion is in agreement with the findings of Wegiel et al. (2018), who reported that intensive thinning is acceptable and more cost-effective for timber production, while a higher density can be more useful for biomass production.

The environmental conditions of the studied stands were monitored by scientists from the Northern Forestry Research Institute from 1960 to 2000 (Chibisov and Nefyodova 2007). According to the data presented by the authors, thinning carried out in the 13-year-old stands impacted microclimatic factors such as lighting, air temperature and humidity, soil freezing depth and thawing rate as well as soil temperature. An impact of thinning on abiotic factors was observed over a period of 40 years and decreased with stand age and top development. In the taiga of northern Europe, temperature is the main ecological factor (Chibisov et al. 2004). In thinned forest stands, higher temperatures facilitate a longer cambium development period and an accelerated cambium cell division (Nefyodova et al. 1984).

The environmental modifications observed within the studied plots probably impacted biocenosis formation; however, studies carried out by the Northern Forestry Research Institute in these plots traditionally covered only growing forest stands.

Other authors have indicated that with forest stand thinning, the growth space for remaining trees is extended, nutrient supply is improved, growth rates are higher and tree distribution in terms of diameter is altered, while branch dying off is slowed down and the branches generally thicken (Chibisov et al. 2004; Sennov 2012; Zakharov 2013). Thinning impacts stand lighting and therefore tree assimilation capacity. Thinning contributes to the formation of needles and leaves, which are more productive than shade needles and leaves (Happanen 1979; Olson 2014).

According to a previous paper, in the course of stand formation via thinning, ground cover and upper soil layers are impacted (Sennov 1977, 1984, 1999; Ledyaeva 2008; Regularities of pine and spruce... 2014). The soil properties developed after thinning impact ecological and coenotic factors, thereby regulating reforestation processes (Osman 2013).

For each type of site, there is an optimal amount of trees providing the most productive stand composition and the most efficient space use, depending on soil and environmental conditions (Popova 1996; Page- 
Dumroese and Jurgensen 2010; Rosenberg and Jacobson 2004). Wood assortment yield depends upon forest growth conditions and stand density (Haapanen 1979; Macdonald and Hubert 2002; Eriksson 2006; Todaro 2011). The impact of thinning intensity on crop yield depends on the location, site and age of the forest stand (del Río et al. 2017).

Thinning also impacts natural regeneration under the canopy, but this impact is related to the species composition of the forest stand (Minkevich 1985; Belyaeva and Kazi 2003; Feklistov and Torbik 2011). Thus, in forest spruce stands of the wood-sorrel type, intensive thinning $(>20 \%)$ can result in ground cover development and natural seeding suppression. At a thinning intensity of $17 \%$, undergrowth develops poorly (Minkevich 1985). After swath thinning in spruce stands of the blueberry type, the spruce undergrowth was sufficient for spruce regeneration at 35 years after the thinning. According to the previous study, the self-seeding undergrowth is less dense in swaths than in skidding lanes (Feklistov and Torbic 2011). Belyaeva and Kazi (2013) have stated that in pine/spruce forest stands of the blueberry type (southern taiga subzone), thinning of lower intensity is more favourable than intensive thinning in respect of forest phytocoenosis preservation. In the middle taiga subzone (Minin 2003), in pine forests of the blueberry type thinned at the age of 30 years $(17,30$ and $43 \%$ of stand volume), spruce undergrowth prevailed, with the occasional pine undergrowth. At 48 years after thinning, undergrowth density was $35-58 \%$ higher than in the reference forest stand.

In our experiments, which were performed in similar taiga sites, species composition modification also occurred: under the pine forest canopy, spruce undergrowth developed. However, its amount depends on the environmental and coenotic conditions formed as a result of young stand thinning and can be related to different ground cover compositions.

Live ground cover in stands formed after thinning impacts seed germination ability, young seedling formation and development as well as tree undergrowth accumulation. However, there is no consent on live ground cover response to thinning. It is generally admitted that at a higher thinning intensity, ground cover modification is more significant due to drastic light changes (Minkevich 1985), resulting in considerable changes in the environmental conditions of the forest phytocoenosis and in unfavourable processes such as bogging (Belyaeva 2009).

The responses of different plant groups and species to thinning depend on the forest type and on the conditions under different thinning intensities. Some scientists state that as a result of improvement cutting, grass species develop (Belyaeva et al. 2009), and the number of species comprising the grass/dwarf shrub storey increases because of the better light conditions (Feklistov and Torbik 2011). However, other studies have shown that this is not always the case (Sennov 1977). Apparently, grass species are less susceptible to thinning than moss species (Abramova and Pulnikov 2009), although information on moss species response is also ambiguous. In some cases, after thinning, the green moss projective cover increased (Sennov 1977), while in other cases (Abramova and Pulnikov 2009), it decreased.

In our experiment, 58 years after thinning, both the grass/dwarf and the moss/lichen communities were altered, and different plant species responded differently to the environmental conditions. Intensive thinning of young stands resulted in improved light conditions; subsequently, light-demanding and xerocolous species developed more vigorously. Lichens appeared in Options 2 and 3, indicating increased insulation and dryer conditions. In the reference stand and the stand with two thinning, lichens were absent.

The upper soil layers show current conditions of biocenosis. According to Chertov (1981), the modification of abiotic factors in ecosystems after thinning significantly impacts the forest floor, potentially increasing the humus layer. The upper O horizon (forest floor) is an important soil layer and represents a biochemical barrier for the migration of chemical elements within the forest biocenosis (Shcherbov 2012); the forest floor saturates the underlying layers with nutrients and water-soluble organic compounds, which migrate via precipitation. Changes taking place in the forest floor as a result of thinning also impact the properties of the mineral soil layers, and in a pine forest stand of the red whortleberry type, thinning resulted in forest floor compaction (Sennov 1977) or quantity reduction (del Rio et al. 2017).

In our experiment, in the two sites, $\mathrm{O}$ horizon thickness increased by 2 times, without soil density modification. In Option 3, due to the reduction of trees to 600 trees/ha, the density of the $\mathrm{O}$ horizon was significantly increased, possibly because of accelerated organ- 
ic matter decomposition due to increased insulation and ground cover composition modification (Dymov et al. 2012). As a result, the $E$ horizon received lower amounts of organic matter.

The gradual modification of environmental and ceonotic conditions via two-stage thinning contributes to a better organic matter supply to the underlying layers. The E horizons of the studied sites contained lower organic matter amounts, but were richer in accumulated organic carbon because of the migration of water-soluble components. In coniferous stands, watersoluble components are saturated with specific humic substances with higher contents of fulvic acids (Lavrentyev et al. 2008), which results in soil organic matter decomposition and can cause podsolization, leading to a greater thickness of the E layer. However, although E layer thickening was observed, there were no significant differences in terms of responses to the environmental conditions. In the southern taiga subzone, thinning mainly results in a decreased soil acidity (Sennov 1999).

\section{Conciusion}

Improvement thinning in young pine/birch stands results in the formation of pure pine stands. The associated modification of environmental properties had no significant impact on natural regeneration, but changed the composition and density of the ground cover and some properties of the upper soil layers. Two-stage improvement thinning had the least impacts on silvicultural and environmental properties; this approach can be used to create stands with high commercial value. It is especially recommended for young pine/birch forests in the northern taiga.

\section{ACKNOWLEDGeMENTS}

We would like to extend our special gratitude to the Northern Forestry Research Institute for the retrospective data about study plots and helpful discussions. We want to thank our colleagues from Laboratory of Agrochemistry and Soil Science (NARFU) for soil sample analysis. The authors also thank two anonymous reviewers for their critical comments on a preliminary version of this article.

\section{FUNDING}

The studies are supported by the RFFI and Arkhangelsk regional government grant № 17-44-290127 'Specific Features of Post-Thinning Northern Taiga Forest Ecosystems Structure and Behavior (Forests of the Arkhangelsk Region as Example)' (Program Manager S.V. Tretyakov).

\section{References}

Ahnlund Ulvcrona, K., Bergström, D., Bergsten, U. 2017. Stand structure after thinning in 1-2 $\mathrm{m}$ wide corridors in young dense stands. Silva Fennica, 51 (3), id 1563, https://doi.org/10.14214/sf.1563

Ares, A, Terry, T.A., Miller, R.E., Anderson, H.W., Flaming, B.L. 2005. Ground - based forest harvesting effects on soil physical properties and Douglasfir growth. Soil Science Society of America Journal, 69, 1822-1832.

Abramova, G.V., Pulnikov, A.P. 2009. Improvement thinning impact on ground cover distribution by agrobotanical groups. Russian Forests and their Economy, 33, 37-42.

Belyaeva, N.V. 2010. Improvement thinning of different intensity impact on stand productivity. Issues of Forest Science and Silviculture. All-Russian Conference Proceedings (ed.: E.N. Nakvasina). Arkhangelsk, 59-62.

Belyaeva, N.V., Grigoryeva, O.I., Fayruzova, O.I. 2009. Improvement thinning impact on live ground cover development. International Research Journal, 9, $75-80$.

Belyaeva, N.V., Kazi, I.A. 2013. Increment thinning impact on vegetation development in lower storeys of pine/spruce forest stands of the blueberry type. Topical Issues of Human and Natural Sciences: collection of papers, 17, 81-90.

Boncina, A., Kadunc, A., Robic, D. 2007. Effects of selective 468 thinning on growth and development of beech (Fagus sylvatica L.) forest stands in SouthEastern Slovenia. Annals of Forest Sciences, 64, 47-57, doi:10.1051/forest:2006087

Burova, N.V., Feklistov, P.A. 2007. Man-induced transformation of forest suburbs. AGTU Press, Arkhangelsk. 
Cambi, M., et al. 2015. Impact of wheeled and tracked tractors on soil physical properties in a mixed conifer stand. iForest, 9, 89-94. doi: 10.3832/ifor1382008

Cameron, A.D. 2002. Importance of early selective thinning in the development of long-term stand stability and improved log quality: a review. Forestry, 75, 25-35. https://doi. org/10.1093/forestry/75.1.25

Cherepanov, S.K. 1995. Vascular plants of Russia and adjoining countries (within the former USSR). World and Family.

Chertov, O.G. 1981. Ecology of wooded lands (Studies of soil and environment in forest areas). Nauka press.

Chibisov, GA, Gushchin VA, Fomin AP, Zakharov $\mathrm{AYu}$ (2011) Silvicultural and economic efficiency of improvement thinning. Practical guide, 2nd ed., Arkhaneglsk: NAFU Press

Chibisov G.A., Nefyodova, A.I. 2007. Improvement thinning and plant climate. Arkhangelsk. Northern Forestry Research Institute.

Chibisov, G.A., Vialykh, N.I., Minin, N.S. 2004. Improvement thinning of forest stands in the European North: Practical guide. ASTU Press, Arkhangelsk.

D’Amore, D.V., Oken ,K.L., Herendeen, P.A., Steel, E.A., Hennon, P. E. 2015. Carbon accretion in unthinned and thinned young-growth forest stands of the Alaskan perhumid coastal temperate rainforest. Carbon Balance and Management, 10, article number: 25 .

Davydov, A.V. 1971. Forest improvement cutting. M. Forestry Publishing House.

del Rio, M., Calama, R., Cañellas, I., Roig, S., Montero, G. 2008. Thinning intensity and growth response in SW-European Scots pine stands. Annals of Forest Science, 65 (3), 308. https://doi.org/10.1051/forest:2008009

del Rio, M., Bravo-Oviedo, A., Pretzsch, H., Löf, M., Ruiz-Peinado, R. 2017. A review of thinning effects on Scots pine stands: From growth and yield to new challenges under global change. Forest Systems, 26 (2). https://doi. org/10.5424/fs/2017262-11325

Dymov, A.A. 2017. Clear cutting impact on soils in boreal forests (review). Soil Science, 7, 787-798.

Dymov, A.A., Bobkova, K.S., Tuzhilkina, V.V., Rakitina, D.A. 2012. Tree waste in primary spruce for- ests and foliage/coniferous stands. Forest Journal, 3, 7-18.

Emmingham, W.H., Elwood, N.E. 2010. Thinning an important timber management tool. Pacific Northwest Extension Publication, Oregon State University Extension Service, PNW 184.

Eriksson, D., Lindberg, H., Bergsten, U. 2006. Influence of silvicultural regime on wood structure characteristics and mechanical properties of clear wood in Pinus sylvestris. Silva Fennica, 40 (4), 743-762. DOI: $10.14214 /$ sf.325

Feklistov, P.A., Torbik, D.N. 2011. Environmental factors modification as a result of improvement thinning in the northern taiga. NAFU, Arkhangelsk.

Forest mensuration handbook for the north-eastern part of Russian Federation. 2012. Pravda Severa, Arkhangelsk.

Formanek, P., Vranova, V. 2003. The effect of spruce stand thinning on biological activity in soil. Journal of Forest Science, 49 (11), 523-530.

Haapanen, C. 1979. Effect of fertilization and thinning on radial growth of Scots pine. Silva Fennica, 13 (2), 184-189.

Hilt, D.E., Dale, M.E. 1989. Thinning even-aged, upland oak stands. USDA Forest service, North central forest experiment station, Central Hardwood Notes, Note 6.06.

Lavrentyev, I.N., Ubugunov, L.L., Ubugunova, V.I. 2008. Organic matter: Ecological features of soil formation and fertility /FGOU VPO Buryatskaya State Agricultural Academy named after V.R. Filippov; Institute of General and Experimental Biology SB of RAS.Ulan-Ude; BSAA Press

Ledyaeva, A.S. 2008. Forest care impact on forest biocenosis components development. Thesis for candidate degree on agriculture. SPb. GLTU Press.

Levkovskaya, M.V., Sarnatsky, V.V. 2013. Some features of aqueous/physical properties of soil modification in pine forests of Brest GPLKhO as a result of mechanical improvement cutting 1(157). BSTU Press.

Lositsky, K.B., Chuenkov, V.S. 1980. Reference forests. Forestry Publishing House.

Lowell, E., Dykstram, C., Monserud, R. 2012. Evaluating effects of thinning on wood quality in SouthEast Alaska. Western Journal of Applied Forestry, 27, 72-83. 
Macdonald, H., Hubert, J. 2002. A review of the effect of silviculture on timber quality of Sitka spruce. Forestry, 2, 107-138. DOI:10.1093/fores try/75.2.107

Mäkinen, H., Isomäki, A. 2004. Thinning intensity and growth of Norway spruce stands in Finland. Forestry, 349-364. DOI: 10.1093/forestry/77.4.349

Markovski, A.V., Rodionov, A.V. 2018. Thinning in young forest: how to develop forestry. Practical guide. WWF, Moscow.

Minin, N.S. 2003. Natural reforestation in pine forests formed as a result of improvement thinning. Vegetation and plant resources of European North of Russia: Proceedings of X Readings from Perfilyev. Arkhangelsk, 123-125.

Minkevich, G.P. 1985. Improvement thinning impact on reforestation and ground cover of spruce forests in southern taiga. Silviculture, artificial stands, soils. Interuniversity collection of papers. LTA, Leningrad, 72-77.

Murphy, G., Firth, J.G., Skinner, M.F. 2004. Long-term impacts of forest harvesting related soil disturbance on log product yields and economic potential in a New Zealand forest. Silva Fennica, 38 (3), 279-289. DOI.org/10.14214/sf.416

Naghdi, R., Solgi, A., Labelle, E.R., Zenner, E.K. 2016. Influence of ground-based skidding on physical and chemical properties of forest soils and their effects on maple seedling growth. European Journal of Forest Research, 135, 949-962.

Nefyodova, A.I., Moskalyova, S.A., Chibisov, G.A. 1984. Plant climate and cambium development in pine forests after improvement thinning. Silvicultural studies based on zones and typology: Collection of scientific papers. Arkhangelsk.

Novàk, J., Dušek, D., Slodičàk, M., Kacàlek, D. 2017. Importance of the first thinning in young mixed Norway spruce and European beech stands. Journal of Forest Science, 63 (6), 254-262.

Oksanen, J. et al. 2017. Vegan: community ecology package. R package version 2.4-4. https://CRAN.Rproject.org/package= $=$ vegan

Olson, M.G., Meyer, S.R., Wagner, R.G., Seymour, R.S. 2014. Commercial thinning stimulates natural regeneration in spruce-fir stands. Canadian Journal of Forest Research, 44, 173-181.

Osman, K. 2013. Forest soils: Properties and management.
Page-Dumroese, D., Abbott, A.M., Rice, T.M. 2009. Forest soil disturbance monitoring protocol, Volume 1: Rapid assessment. Washington DC: USDA Forest Service.

Page-Dumroese, D., Martin, J., Thomas, T. 2010. Maintaining soil productivity during forest or biomass-toenergy thinning harvests in the western United States. Western Journal of Applied Forestry, 5 (1), 7-11.

Popova, E.P., Perevoznikova, V.D. 1996. Transformation of the lower layers of vegetation and litter on felled areas of pine forests in the middle Angara region. Lesovedenie, 6, 47-57.

R CoreTeam. 2017. R: A Language and environment for statistical computing. R Foundation for Statistical Competing, Vienna, Austria. URL http:// www.R-project.org/

Regularities of pine and spruce phytocenosis development within improvement thinning and stand carding areas. 2014. Polytechnic University Press.

Rosenberg, G.S. 2012. Paul Jaccard and environmental components similarity. Samarian Bend. Issues of Regional and Global Ecology, 21 (1), 190-202.

Rosenberg, O., Jacobson, S. 2004. Effects of repeated slash removal in thinned stands on soil chemistry and understorey vegetation. Silva Fennica, 38, 133-142. https://doi.org/10.14214/sf.423

Rytter, L., Werner, M. 2007. Influence of early thinning in broadleaved stands on development of remaining stems. Scandinavian Journal of Forest Research, 22 (3), 198-210.

Saramiaki, Yu. 1992. Bases of experimental cutting applied by the Forestry Research Institute, Finland. Russian-Finnish workshop on improvement thinning. November 9-11. University of Joensu, Forestry department №7, 51-56.

Sennov, S.N. 1984. Forest care (ecological bases). Forestry Publishing House.

Sennov, S.N. 1977. Forest improvement thinning: monograph. Forestry Publishing House.

Sennov, S.N. 2012. Improvement thinning impact on final growing stock. Proceedings of the Saint Petersburg Forestry Research Institute, 1/2, 8-10.

Sennov, S.N. 1999. Results of 60-year observations of natural forest development. Forestry Research Institute Proceedings.

Shcherbov, B.L. 2012. Forest floor impact on chemical elements and artificial radionuclides migration on 
forest fires in Siberia. Siberian Ecological Journal, 2, 253-265.

Solgi, R., Naghdi, R., Tsioras, P.A., Nikooy, M. 2015. Soil compaction and porosity changes caused during the operation of Timberjack 450C skidder in Northern Iran. Croatian Journal of Forest Engineering, 36 (2), 217-225.

Swift, D.E., Knight, W., Béland, M., Boureima, I., Bourque, C., Meng, F.R. 2016. Stand dynamics and tree quality response to precommercial thinning in a northern hardwood forest of the Acadian Forest Region: 23 years of intermediate results. Scandinavian Journal of Forest Research, 32 (1), 1-45.

Todaro, L., Macchioni, N. 2011. Wood properties of young Douglas-fir in Southern Italy: Results over a 12-year post-thinning period. European Journal of Forest Research, 130, 251-261. DOI: 10.1007/ s10342-010-0425-9

Trubin, D.V., et al. 2000. Dynamics and prospects for forest use in the Arkhangelsk Region. ASTU Press.

Węgiel, A., Bembenek, M., Lacka, A., Mederski, P.S. 2018. Relationship between stand density and value of timber assortments: a case study for Scots pine stands in North-Western Poland. New Zealand Journal of Forestry Science, 48, 12.

Zakharov, A.Yu. 2013. Silvicultural and economic efficiency of improvement thinning in pine forests of the middle taiga subzone of the Arkhangelsk Region. Northern (Arctic) Federal University, Arkhangelsk. 